\title{
MONITORING OF PHYTOREMEDIATING WETLAND MACROPHYTES USING REMOTE SENSING: THE CASE OF COMMON REED (PHRAGMITES AUSTRALIS (CAV.) TRIN. EX STEUD.) AND THE GIANT REED (ARUNDO DONAX L.). A REVIEW
}

\author{
MABhungu, L. ${ }^{1 *}-$ AdAM, E. ${ }^{1}-$ Newete, S. W. ${ }^{2,3}$ \\ ${ }^{1}$ School of Geography, Archaeology and Environmental Studies \\ University of the Witwatersrand, Private Bag X3, 2050 Johannesburg, South Africa \\ ${ }^{2}$ Agricultural Research Council-Institute for Soil, Climate and Water (ARC-ISCW) \\ Geo-Information Science Programme, Arcadia, Private Bag X79, 0001 Pretoria, South Africa \\ ${ }^{3}$ School of Animal, Plant and Environmental Sciences, University of the Witwatersrand \\ Private Bag X3, 2050 Johannesburg, South Africa \\ *Corresponding author \\ e-mail: loveness.mabhungu@gmail.com \\ (Received $7^{\text {th }}$ Nov 2018; accepted $25^{\text {th }}$ Jan 2019)
}

\begin{abstract}
Contaminants from various anthropogenic activities such as agriculture, mining, and recreation negatively affect wetland water quality and vegetation health and composition. Phytoremediation is an effective, sustainable and eco-friendly pollution abatement method using green plants. Arundo donax $\mathrm{L}$. and Phragmites australis (Cav.) Trin. ex Steud. are two morphologically similar reeds commonly used for phytoremediation in wetlands of South Africa. Arundo donax is however, a declared category ' $1 \mathrm{~b}$ ' weed under the National Environmental Management: Biodiversity Act (NEM:BA, Act No. 10 of 2004), requiring its immediate removal. Thus, determining the phytoremediation efficiency of the two reeds could help making the right choice between them for potential use in wetlands. Furthermore, the effeciency of wetlands depends on a robust monitoring system for phytoremediating plants to determine the appropriate time for biomass harvest before they die and release contaminants taken up in plant tissues back into the source through decomposition. Remote sensing can be used for mapping and monitoring of such aquatic macrophytes at species level effectively. Satellites imageries with high spatial and spectral resolutions not only are capable of detecting heavy metal-induced plant stresses, but also can effectively discriminate between morphologically similar species like A. donax and P. Australis and facilitate wetland managment.
\end{abstract}

Keywords: Acid Mine Drainage; Heavy metal uptake, Maping; hyperspectral; Rhizofiltration

\section{Introduction}

Phytoremediation is a relatively low-cost and environmentally friendly method of reducing environmental pollutants to harmless levels using green plants (Emmanuel et al., 2014; Kaewtubtim et al., 2016; Newete and Byrne, 2016). Based on the plant tissues involved in removal of pollutants and their specific sites of accumulation in the plants, phytoremediation is sub-categorized as phytoextraction, rhizofiltration, phytovolotalization, phytostabilization, phytodegradation, and rhizodegradation (PilonSmits, 2005; Newete and Byrne, 2016). Phytostabilisation refers to the process of plants stabilising pollutants in the soil to harmless levels; phytoextraction is when pollutants are transported and concentrated in the above ground plant tissues and involves subsequent harvest of aerial plant biomass; rhizofiltration is when plants, or 
microorganisms associated with the rhizosphere, remove contaminants from water; phytodegradation occurs when plant enzymes break down pollutants inside their tissues and convert them into harmless compounds; phytovolatilisation involves extraction of volatile compounds by plants which are released as volatile compounds through the leaves (Raskin, 1997; Wong, 2003). Phytoremediation can occur in both dry and wet environments. Phytoextraction is commonly used for cleaning contaminants from soil, rhizofiltration to clean contaminants from water medium, while phytostabilization, phytovolatilization and phytodegradation can be used to clean either from soil or water mediums (Frick et al., 1999; Wong, 2003; Yang et al., 2005). The degree of pollutant accumulation by plants tends to increase with the wetness of the environment (Aryal et al., 2016). Compared to conventional or engineering methods of cleaning polluted environments, phytoremediation is potentially cheaper, environmentally friendly, sustainable, and has the possibility of bio-recovering heavy metals (Yang et al., 2005).

According to Ramsar Convention Secretariat (2016) wetlands are "areas of marsh, fen, peatland or water, whether natural or artificial, permanent or temporary, with water that is static or flowing, fresh, brackish or salt, including areas of marine water the depth of which at low tide does not exceed six metres". Wetlands are essential to both humans and the ecological environment, and once their health and functions are disturbed, the effects are detrimental on all life forms supported by wetlands. Their functions include nutrient removal from water, trapping of sediments, pollutant trapping, control of erosion, stream flow augmentation, provision of habitat for wildlife, and recreational benefits (Bruneau, 2017; Luo et al., 2017). According to Zedler and Kercher (2004), wetlands account for approximately $6 \%$ of the world's land surface. Depending on their positioning, wetlands are subjected to impacts from human activities such as agriculture, mining and urban development. Impacts of mining on wetlands include water pollution from Acid Mine Drainage (AMD) and heavy metals, land degradation, vegetation biodiversity degradation, and destruction of a wide range of habitat for wetland wildlife (Gupta and Nikhil, 2016). From these, the major effect of mining activities on wetlands is AMD pollution, which emanates from seepage of both active and abandoned mining areas near wetlands (Newete and Byrne, 2016). Acid mine drainage is the outflow of acidic water from mining sites, and this is mainly due to the oxidation of iron pyrites $\left(\mathrm{FeS}_{2}\right.$ ) (Akcil and Koldas, 2006; Ochieng et al., 2010). Due to its low pH of usually $2-3$, AMD dissolves mining ores, and thus contains, high concentrations of metals which include manganese, aluminum, iron, nickel, zinc, cobalt, copper, and cadmium (Bell et al., 2001; Coetzee et al., 2006). AMD pollution from wetlands can also end up in streams, rivers and dams, which supply potable water for humans (McCarthy and Humphries, 2013). This makes the water quality unsuitable for human consumption and adds a toll to the costs of water purification. Research has shown that low $\mathrm{pH}$ and high concentrations of heavy metals negatively affect wetland species composition (Ochieng et al., 2010). Destruction of wetland vegetation or alteration of vegetation composition will also affect wild animals which use the plants as habitats. However, some aquatic plant species have adapted mechanisms to survive in such conditions (Deng et al., 2004; Papazoglou et al., 2005; Vymazal and Březinová, 2015), thus, they can be used as bio-indicators to evaluate the presence and amount of heavy metal contaminants in wetlands. These plants have an extensive root system and root surface area that enhances contaminant uptake by adsorption of metal cations onto the negatively charged root surfaces (Newete et al., 2016; Newete and Byrne, 2016). The subsequent harvest of the phytoremediating plants with a cocktail of organic and 
inorganic contaminants from polluted wetlands means an improvement of the existing water quality. Thus, many artificial wetlands are constructed for treatment of wastewater using green plants (Liu et al., 2007; Vymazal and Březinová, 2015). Among the common emergent macropytes used in wetlands are Phragmites australis (Cav.) Trin. ex Steud. (Vymazal and Brezinova, 2016), Arundo donax L. (Elhawat et al., 2014), Phalaris arundinacea Scirpus spp. and Typha spp. (Papazoglou et al., 2005; Newete and Byrne, 2016). From these, P. australis is the most commonly used and studied plant species (Vymazal and Brezinova, 2016). This could be because it is a cosmopolitan plant species which is widely distributed across the world (Adams and Bate, 1999). Arundo donax L., which is morphologically similar to P. australis, is another such species with wide geographical distribution in many polluted wetland systems of South Africa outside its natural habitat (Rouget et al., 2004). Phragmites australis also known as common reed, is native to South Africa (Adams and Bate, 1999), while A. donax, known as the Spanish or the giant reed, is a declared Category 1b weed in South Africa (Henderson, 2001; Department of Environmental Affairs, 2016). Although the two reeds have proved to be effective as tools of phytoremediation in wetlands, their capacities to uptake heavy metals have not been compared under similar and controlled conditions.

Although the efficiency of metal uptake by phytoremediating plants depends on plant species, size of plant biomass particularly large root surface area in aquatic macrophytes, type and amount of elements targeted for removal (Newete and Byrne, 2016), it is equally important to monitor the level of such pollutants' removal from the polluted environment and accumulation in the plant tissues. This is because it allows subsequent management of the phytoremediating plants by determining the appropriate time for harvest of plant biomass and safe disposal (Carson et al., 2018). The conventional method of determining metal accumulation in plant tissue in the laboratory is often expensive, destructive and labour intensive (Van Deventer and Cho, 2014). Thus, there is a need for effective and non-destructive method to monitor heavy metal uptake by various wetland plants. Remote sensing has the potential to be that method. This is because the spectral reflectance by green vegetation depends, inter alia, on the amount of specific biochemical in plant leaves (Gates et al., 1965; Zwiggelaar, 1998). Remote sensing has extensively been used to monitor the effect of individual metal pollutants on plants using their effects on chlorophyll and net photosynthesis (Sridhar et al., 2007).

There is a large number of literature reviews on phytoremediation (Raskin et al., 1997; Pilon-Smits, 2005; Laghlimi et al., 2015; Rizwan et al., 2017) and for wetlands (Matagi et al., 1998; Usharani and Vasudevan, 2016; Newete and Byrne, 2016; Leguizamo et al., 2017). However, only few of them focused on wetland phytoremediating plants. This study will therefore, review the efficiency of phytoremediation by emergent aquatic macrophytes in wetlands with specific reference to two morphologically similar reeds, $P$. australis and A. donax, in South Africa. It will also investigate the potential of remote sensing technique in monitoring heavy metal accumulation by the plants effectively. 


\section{Reeds in South Africa}

Reed is the general botanical term used for tall, grass-like plants that grow in wet places. They occur in reed beds. They are all members of the order Poales, but under different families. Table 1 gives a list of some of the commonly known reeds.

Table 1. Some of commonly known reeds in the world

\begin{tabular}{|c|c|}
\hline Family & Reed's common name and species name \\
\hline \multirow{6}{*}{ Poaceae grass } & Common reed (Phragmites australis (Cav.) Trin. ex Steud.) \\
\hline & Giant reed (Arundo donax L.) \\
\hline & Burma reed (Neyraudia reynaudiana) \\
\hline & Reed canary-grass (Phalaris arundinacea) \\
\hline & Reed sweet-grass (Glyceria maxima) \\
\hline & Small-reed (Calamagrostis species) \\
\hline Cyperaceae (sedge) & Paper reed or papyrus (Cyperus papyrus) \\
\hline Sparganiaceae & Bur-reed (Sparganium species) \\
\hline Typhaceae & Reed-mace (Typha species) \\
\hline \multirow{2}{*}{ Restionaceae } & Cape thatching reed (Elegia tectorum) \\
\hline & Thatching reed (Thamnochortus insignis) \\
\hline
\end{tabular}

From the list in Table 1, Cyperus papyrus, A. donax, Calamagrostis species, $P$. australis and Typha species were identified in wetlands of South Africa (De Villiers et al., 2011). Cyperus papyrus is a tall perennial grass-like emergent plant. It is naturally found in KwaZulu-Natal, Mpumalanga and Limpopo provinces. It grows along the edges of rivers, seasonal or permanent pools, or swamps. The reed is unpalatable and has low forage quality, and thus does not support many plantivores (De Villiers et al., 2011). Calamagrostis is a perennial grass which inhabits vleis and marshes. It is sparsely distributed in Eastern Cape, Mpumalanga, Gauteng, North West and Northern Cape provinces of South Africa (De Villiers et al., 2011). Typha species is widely distributed in South Africa and it grows in wetlands and all aquatic habitats (Masoko et al., 2008; Ilfergane, 2016). The species forms large dense and dominant stands. Arundo donax and $P$. australis are tall, robust and perennial grass-like plants with hollow stems, and are widely distributed in Western Cape, Eastern Cape, KwaZulu-Natal, Mpumalanga and Gauteng provinces of South Africa (De Villiers et al., 2011). Morphologically the two reeds resemble each other. They are both aggressive invaders outside their native ranges (Lambert et al., 2010). The slight differences between them are shown in Table 2, extracted from Lusweti (2011). Images for A. donax (Fig. 1) and P. australis (Fig. 2) in Johannesburg, South Africa, extracted from google earth, are also shown below.

Table 2. Morphological differences between Phragmites australis (Cav.) Trin. ex Steud. and Arundo donax $L$.

\begin{tabular}{l|l}
\hline Arundo donax $\boldsymbol{L}$. & Phragmites australis $($ Cav.) Trin. ex Steud. \\
\hline Very tall grass, $2-7 \mathrm{~m}$ tall & relatively tall grass, $1.5-3 \mathrm{~m}$ tall \\
Relatively broad leaves, $10-80 \mathrm{~mm}$ wide & relatively narrow leaves $10-35 \mathrm{~mm}$ wide \\
\hline
\end{tabular}

Arundo donax L. is native to the Mediterranean Basin and the middle east in Asia, and some parts of Africa and southern Arabian Peninsula, while P. australis is a cosmopolitan species with wide distribution spanning the five continents (excluding the polar continents) of the world, and it is also known as native to South Africa 
(Henderson and Cillier, 2004). Arundo donax L. is a naturalised alien species in South Africa (Milton, 2004), and was introduced in the late 1700s for soil erosion control. It invades riparian areas across South Africa and its spread is facilitated by human activities such as building of dams and soil stabilisation (Canavan et al., 2017). Alien invasive plant species have negative impacts on indigenous plant ecosystems. They form dense stands which reduce biodiversity of indigenous communities, affect foodwebs, and hence change ecosystem processes (Milton, 2004). Arundo donax L. is highly flammable and can alter fire regimes in invaded areas, thus changing the communities of native plants into a dense mono stand of A. donax (Lusweti, 2011). To address the invasive potential and negative impacts of A. donax in South Africa, biological control methods are being considered (Canavan et al., 2017).

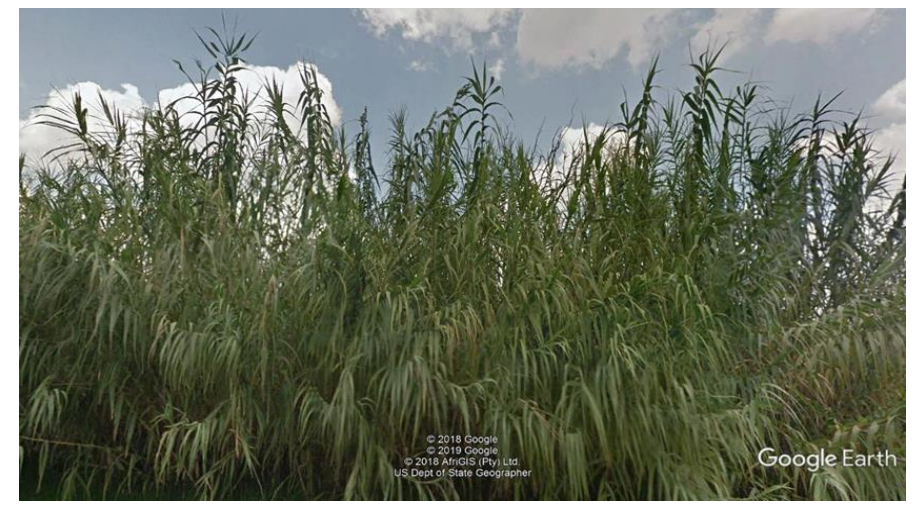

Figure 1. Image of the giant reed (Arundo donax). Source: US Department of State Geographer, Google earth, 2018.

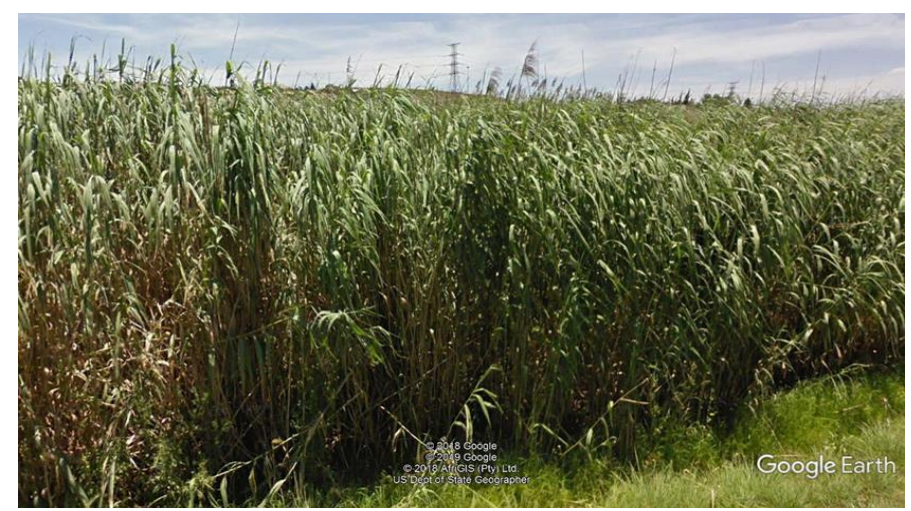

Figure 2. Image of the common reed (Phragmites australis). Source: US Department of State Geographer, Google earth, 2018.

Both A. donax and P. australis can adapt well in both dry and damp or wet areas, as well as in heavily polluted areas. As such, they are common in most wetlands. Their dense stands often crowds or shade other wetland vegetation. Their ability to uptake and accumulate nutrients and other pollutants makes them the most suitable macrophytes for phytoremediation in polluted wetlands (Bonanno, 2012; Aminsharei et al., 2017; Bello et al., 2018). As such the two plants have been used for phytoremediation in constructed and natural wetlands. 


\section{Phytoremediation by aquatic plants}

Wetland vegetation is an important part of the wetland ecosystem, as it plays a major role in environmental sustainability (Adam et al., 2010). Naturally wetlands are sinks for many contaminants, and as such they accumulate materials resulting from both terrestrial and wetland disturbances like sediments, nutrients, salts, heavy metals and other contaminants (Kaplan et al., 2017). According to De Villier et al. (2011), 50\% of wetlands in South Africa have already been destroyed due to anthropogenic activities such as agriculture, mining, and urban development. Disturbances from these activities negatively affect the native wetland ecosystems. As a result of this, wetlands are vulnerable to invasion, and presence of particular invasive macrophytes in a wetland may be an indicator of the status of the wetland medium and system (Zedler and Kercher, 2004). Most invasive macrophytes are hyper-accumulators and have the ability to absorb harmful substances and pollutants from the wetland medium into their plant tissues (Zedler and Kercher, 2004). High concentration of pollutants in plant tissues is an important indicator of water quality status in wetlands and other water systems (Deng et al., 2004; Allende et al., 2011). All forms of aquatic plants (emergent, submerged and floating aquatic species) are used for phytoremediation of polluted wetlands (Newete and Byrne, 2016). Nevertheless, emergent aquatic macrophytes like $P$. australis ( and $A$. donax are more prevalent in most wetland systems and have proven to be more resilient and effective in removal of heavy metals (Sheoran and Sheoran, 2006; Yang et al., 2006). The degree to which plants accumulate heavy metals is determined by the individual plant uptake capacity and intracellular transportation within the plant (Yang et al., 2005). For example $P$. australis has the potential to accumulate $\mathrm{Cd}, \mathrm{Cu}, \mathrm{Cr}, \mathrm{Ni}$ and $\mathrm{Pb}$ up to $0.1 \%$ of plant dry mass and $\mathrm{Fe}$ and $\mathrm{Zn}$ up to $1 \%$ plant dry mass (Kalra, 1998; Sasmaz et al., 2008). Research conducted by Yang et al. (2006) in Guangdon province, China, showed that Typha latifolia, P. australis and Cyperus malaccensis significantly removed $94 \%$ of $\mathrm{Cd}, 99.04 \%$ of lead $(\mathrm{Pb})$, and $97.30 \%$ of zinc $(\mathrm{Zn})$ from a constructed wetland. Vymazal and Březinová (2016) revealed that $P$. australis planted in constructed wetlands removed $59 \% \mathrm{Zn}, 55 \% \mathrm{Cd}$ and $38 \% \mathrm{Cr}$, from the inflow annual load of the metals into wetlands. Vymazal and Březinová (2016) also concluded that the plant shoots in constructed wetlands can sequester up to $55 \% \mathrm{Cr}, 49 \% \mathrm{Zn}$ and $71 \% \mathrm{Cd}$, of the total heavy metals removed by the $P$. australis. In another study 19 plant species, among which were $P$. australis and Cyperus species, were planted in a constructed wetland in China and irrigated with waste water containing concentrations of $\mathrm{Zn}, \mathrm{Cd}$ and $\mathrm{Pb}$ at 5.0, 0.5 and $2.0 \mathrm{mg} / \mathrm{L}$, respectively. The results showed that the plants had more than $90 \%$ removal efficiency for the heavy metals (Liu et al., 2007). Bello et al. (2018), in Saudi Arabia, investigated the capacity of $P$. australis in removing $\mathrm{Cd}, \mathrm{Pb}$ and $\mathrm{Ni}$ in hydroponic experiments with $5 \mathrm{mg} / \mathrm{L}$ concentration for each heavy metal. The results showed that the capacity of heavy metal removal by P. australis was $93 \%, 95 \%$ and $84 \%$ for $\mathrm{Cd}, \mathrm{Pb}$ and $\mathrm{Ni}$, respectively. In another research conducted in Catania, Italy, the roots, stems, and leaves of $A$. donax were tested as potential bio-monitors of trace elements such as $\mathrm{Al}, \mathrm{As}, \mathrm{Cd}, \mathrm{Cr}, \mathrm{Cu}, \mathrm{Hg}, \mathrm{Mn}, \mathrm{Ni}, \mathrm{Pb}$, and $\mathrm{Zn}$. The results showed that $A$. donax had the capacity to significantly bioaccumulate the trace elements, with root/sediment Bioaccumulation factors of: $\mathrm{Cr}(0.08), \mathrm{Cu}(0.05), \mathrm{Mn}(0.02), \mathrm{Ni}(0.1)$, and $\mathrm{Pb}$ (0.03) (Bonanno, 2012). Mojiri et al. (2015) investigated the effectiveness of $P$. australis for heavy metal uptake from municipal waste leachate. At the end of their experiment, the amount of $\mathrm{Fe}, \mathrm{Mn}, \mathrm{Cu}$ and $\mathrm{Ni}$ removed by $P$. australis were 25.049, $9.623,6.112$, and $0.900 \mathrm{mg} / \mathrm{kg}$, respectively. The translocation factors were $0.34,0.89$, 
1.30 and 1.01, respectively. Translocation Factor (TF) is the ratio of metal concentration in shoots to the metal concentration in roots, and measures the ability of a plant to translocate metals from roots to shoots (Mojiri et al., 2015). A plant has potential to be used for phytoextraction when its TF for a particular metal is above 1 . Thus, according to Mojiri et al. (2015), it is apparent that $P$. australis has the potential for the phytoextraction of $\mathrm{Cu}$ and $\mathrm{Ni}$, from wetlands, but not for Fe and $\mathrm{Mn}$.

Aquatic plants are very useful in natural and constructed wetlands in the abatement of water contaminants and improving the water quality for domestic and agricultural purposes. Table 3 is a summary of some literature showing the removal of heavy metals from contaminated wetlands by aquatic macrophytes.

Table 3. Removal of heavy metal contaminants from wetlands by aquatic macrophytes

\begin{tabular}{|c|c|c|c|}
\hline Species & Metals purified & Place & Reference \\
\hline $\begin{array}{l}\text { Typha capensis and Arundo, } \\
\text { donax L. }\end{array}$ & $\mathrm{Zn}, \mathrm{Mn}, \mathrm{Ni}$ and $\mathrm{Fe}$ & $\begin{array}{l}\text { Johannesburg, South Africa; } \\
\text { Natural wetland }\end{array}$ & Van der Merwe et al., 1990 \\
\hline Cyperus vaginatus & $\begin{array}{l}\mathrm{Cr}, \mathrm{Mn}, \mathrm{Fe}, \mathrm{Co}, \mathrm{Ni}, \mathrm{Cu}, \mathrm{Zn} \text {, } \\
\mathrm{Cd} \text {, and } \mathrm{Pb}\end{array}$ & $\begin{array}{l}\text { South Australia; Constructed } \\
\text { wetland }\end{array}$ & Aryal et al., 2016 \\
\hline $\begin{array}{l}\text { Typha domingensis, } \\
\text { Phragmites australis (Cav.) } \\
\text { Trin. ex Steud. and Arundo } \\
\text { donax L. }\end{array}$ & $\begin{array}{l}\mathrm{Al}, \mathrm{As}, \mathrm{Cd}, \mathrm{Cr}, \mathrm{Cu}, \mathrm{Hg}, \mathrm{Mn} \\
\mathrm{Ni}, \mathrm{Pb}, \mathrm{Zn} .\end{array}$ & Italy; Natural wetland & Bonanno, 2013 \\
\hline $\begin{array}{l}\text { Phragmites australis (Cav.) } \\
\text { Trin. ex Steud. and } \\
\text { Bolboschoenus maritimus }\end{array}$ & $\mathrm{Cr}, \mathrm{Ni}, \mathrm{Cu}$ and $\mathrm{Zn}$ & $\begin{array}{l}\text { Northeast Italy; Constructed } \\
\text { wetland }\end{array}$ & Bragato et al., 2006 \\
\hline $\begin{array}{l}\text { Bolboschoenus } \\
\text { Maritimus }\end{array}$ & $\mathrm{Al}, \mathrm{Fe}, \mathrm{Cu}, \mathrm{Zn}$ & $\begin{array}{l}\text { Western Cape, South Africa; } \\
\text { Natural wetland }\end{array}$ & Shuping et al., 2011 \\
\hline
\end{tabular}

The efficiencies of $P$. australis and A. donax in heavy metal uptake have been studied by a number of researchers worldwide (Papazoglou et al., 2005; Bonanno, 2012; Kumari and Tripathi, 2015), including in South Africa (Van der Merwe et al., 1990; Zingelwa and Wooldridge, 2016). Kumari and Tripathi (2015) demonstrated the removal of $\mathrm{Cu}, \mathrm{Cd}, \mathrm{Cr}, \mathrm{Ni}, \mathrm{Fe}, \mathrm{Pb}$ and $\mathrm{Zn}$ from urban sewage mixed with industrial effluents using $P$. australis and $T$. latifolia, as a cost effective and promising technology in India. Their resuts showed that $P$. australis perfomed better than $T$. latifolia for all the metals, and mixing the two plants increased the removal efficiency of the metals from the effluent. Papazoglou et al. (2005) investigated A. donax irrigated with tap water containing increased concentrations of $\mathrm{Cd}$ and $\mathrm{Ni}$ in Greece. At the end of the experiment the parameters measured, namely, stem height and diameter, number of nodes, fresh and dry weight of leaves, and net photosynthesis, were found not affected, indicating that $\mathrm{A}$. donax tolerates high concentrations of $\mathrm{Cd}$ and $\mathrm{Ni}$, and thus can be used for phytoremediation. Van der Merwe et al. (1990) measured the accumulation of $\mathrm{Zn}, \mathrm{Mn}, \mathrm{Ni}$ and Fe by $A$. donax and T. capensis under acidic and alkaline conditions in the Burgspruit catchment area near Germiston, Ekurhuleni, South Africa and concluded that the metal accumulation capacity of A. donax was higher than that of $T$. capensis. Zingelwa and Wooldridge (2016) studied the mineral element uptake and accumulation by $T$. latifolia and $P$. australis from waste water in constructed wetlands in South Africa. They found that $T$. latifolia accumulated more mineral elements $(\mathrm{N}, \mathrm{P}, \mathrm{K}, \mathrm{Ca}$ and $\mathrm{Al}$ ) than $P$. australis. However, only few or no studies compared the capacities of A. donax and $P$. australis in heavy metal accumulation under experimental or controlled environment. Bonanno (2013) compared the trace element bioaccumulation capacities 
of the two plant species under field or natural conditions, and the results showed that $P$. australis is a better heavy metal accumulator than A. donax. He measured the heavy metals $\mathrm{Al}, \mathrm{As}, \mathrm{Cd}, \mathrm{Cr}, \mathrm{Cu}, \mathrm{Hg}, \mathrm{Mn}, \mathrm{Ni}, \mathrm{Pb}$, and $\mathrm{Zn}$ in Typha domingensis, $P$. australis and $A$. donax naturally growing along a stream in Italy. The results showed that the bioaccumulation capacities decreased in the order of root>stem $>$ leaf in $T$. domingensis, and root>leaf $>$ stem in $P$. australis and A. donax. Generally the bioaccumulation capacities for $P$. australis and T. domingensis were found to be higher than that of $A$. donax. Thus, if the native $P$. australis is more effective in removal of heavy metals than its counterpart $A$. donax in wetlands, it is imperative to promote the former species to eventually replace the notorious invader A. donax in wetlands. However, to ascertain this, future research should focus on comparing the heavy metal uptake capacities of the two plant species under controlled/experimental conditions. This is because they are widely distributed in many parts of the country and they both provide similar economic and ecological functions. They are useful as thatching, ornamental and musicalinstrument (like flutes) materials and source of energy, and wildlife habitat (Bonanno, 2012; Shuai et al., 2016). However, because of their similar morphology, discrimination between the two species and monitoring their occurrence and their environmental foot prints in the field is difficult.

\section{Methods of monitoring heavy metal uptake by aquatic macrophytes}

While many aquatic macrophytes have proven to be valuable for phytoremediation, the process requires continuous monitoring to ensure timely harvest of plant biomass and thier replacement for continuous and effective removal of water contaminants (Carson et al., 2018). Appropriate tool of monitoring is required to determine the heavy metal accumulation in the phytoremediating plant tissues and their health status to avoid metal-induced stress and subsequent death of plant tissues before their harvest and removal (Vassilev et al., 2004). Traditional methods of monitoring heavy metal uptake by plants involve sampling plant tissues and sample preparation for laboratory analysis. For example tree-ring analysis, which involves chemical analysis of samples from successive growth rings, can be done to monitor patterns of heavy metal uptake by plants over years (Lepp, 1975). In the same manner samples of plant roots, stems, and leaves can be analysed in the laboratory to determine the heavy metal uptake ability by plants (Vymazal and Brezinova, 2016). However, for monitoring large areas, traditional surveys involve lots of plant sample collection and preparation, which may be difficult, expensive, too technical, time consuming and poses safety issues on chemical handling and disposal. Sampling of representative plant tissue could also be constrained due to inaccessiblity. Remote sensing is a modern and alternative technology for monitoring such wetland phytoremediating plants. It is also an effective, non-destructive tool for monitoring heavy metal accumulation by wetland plants (Van Deventer and Cho, 2014). Remote sensing can be used to acquire spatial and temporal variations of accumulated heavy metal concentrations over large and inaccessible areas, as opposed to the in-situ traditional methods which are limited to small and accessible areas (Liu et al., 2010).

\section{Monitoring of heavy metal uptake by wetland plants with remote sensing}

Remote sensing is the technology of obtaining information about an object without a direct contact to the object under observation. Monitoring of vegetation using remote sensing is possible because vegetation under different conditions and of different 
characteristics and quality has unique spectral characteristics in the electromagnetic spectrum (Knipling, 1970). The spectral response properties of vegetation are determined by the biochemical content (e.g. chlorophyll) and anatomical (e.g. canopy architecture) structure of their leaves or crowns (Curran, 1989). All vegetation has a spectral response curve, which is unique to each species. High chlorophyll levels result in increased absorption (reduced reflection) in the red region of the electromagnetic spectrum, and broadening of the absorption pit in the red $(660-680 \mathrm{~nm}$ ) (Horler et al., 1983). It also shifts the red edge reflectance slope $(680-760 \mathrm{~nm})$ and the point of maximum slope in the red edge known as the chlorophyll red edge position (REP) towards the longer wavelengths, referred to as a red shift (Horler et al., 1983). Accordingly, decreased chlorophyll results in increased reflectance in the red region, and a shift of the red edge slope and REP towards the shorter wavelengths, which is referred to as a blue shift. Increases in biomass increases reflection in the near-infrared (NIR) region (Rouse Jr., 1974). Various heavy metal concentrations also have significant effects on the spectral reflectance properties of leaves. According to Sridhar et al. (2007), $\mathrm{Zn}$ accumulated in plant leaves causes a blue shift in the REP and a decrease in NIR reflectance. Accumulated Cd also results in a blue shift of REP and overall increase of reflectance in the visible region (Sridhar et al., 2007). Lead results in increased reflectance in the NIR region (Clevers et al., 2004). Liu et al. (2010) studied the possibility of using a small scale hand held hyperspectral sensor to estimate heavy metal $(\mathrm{Pb}, \mathrm{Cu}$ and $\mathrm{Zn})$ concentrations in $P$. australis. The study revealed that heavy metal concentrations affected chlorophyll levels in the plants, which in turn determine the hyperspectral measurements for the plant leaves. It was also found that chlorophyll concentrations for the sampled leaves varied inversely with concentrations of $\mathrm{Pb}, \mathrm{Cu}$ and $\mathrm{Zn}$, and chlorophyll concentration accounted for about $30 \%$ of the variations in the three heavy metals, respectively. Linear combination of normalized band depths at wavelengths 537 (green), 667 (red) and 747 (near infrared) nm were found to explain $82 \%$ of the variation of chlorophyll concentration (Liu et al., 2010). Thus it was concluded that it is possible to use laboratory-based hyperspectral data to estimate concentrations of $\mathrm{Pb}, \mathrm{Cu}$ and $\mathrm{Zn}$ in $P$. australis (Liu et al., 2010). In another study, Shakya et al. (2008) also concluded that high concentrations of heavy metals in plants determine their chlorophyll content, which can be measured by field hyperspectral data or hyperspectral images. Research by Li et al. (2008) investigated the biogeochemistry responses of vegetation Rhus chinensis Mill in a copper mine area to heavy metal contamination. The results showed that there was a significant correlation between copper concentration in leaves and leaf reflectance. Increased copper concentrations were found to: increase the leaf spectral reflectance by about $5 \%$ to $30 \%$, cause a blue shift of about 5 to $15 \mathrm{~nm}$, increase the red edge from 4.5534 to $8.9475 \mathrm{~nm}$ and decrease the chlorophyll absorption depth. Thus, remote sensing can be used to differentiate between healthy and stressed vegetation and to determine the level of specific heavy metals in plants. Some plants used for phytoremediation in wetlands like $P$. australis and A. donax are morphologically similar, and it is also important to be able to discriminate between such species using remote sensing.

\section{Use of remote sensing to discriminate wetland plant species}

Successful management of wetlands requires proper and up to date mapping and discrimination of wetland plants (Hirano et al., 2003; Davranche et al., 2010). While the physical methods of mapping and discriminating wetland vegetation are time 
consuming and have accessibility and many other logistical problems, remote sensing can be an effective alternative for such purpose. Discrimination of plant species using remote sensing is possible because different vegetation types reflect differently to electromagnetic radiation. Plant leaves of different plant species have different biophysical and biochemical characteristics, and these affect their leaves' spectral properties, and make it possible to discriminate between different plant species (Kurmar et al., 2001). Extensive research has been done using remote sensing to discriminate between plant species (Adam et al., 2010). For example, Dubula et al. (2016) proved the potential of remote sensing in discriminating invasive plant species in the Klipriviersberg nature reserve in Johannesburg, South Africa. Their research concluded that at both individual level and plot level, the near infrared region of the electromagnetic spectrum could be used to discriminate between Asparagus laricinus and other vegetation species in the nature reserve. $\mathrm{Pu}$ (2009) used spectrometry to identify 11 forest species. They concluded that two classification algorithms, Artificial Neural network (ANN) and Linear Discriminant Analysis (LDA) were effective in discriminating plant species using selected spectral variables that are linked to water content, pigments and other biochemical.

Even though remote sensing is proved as a practical and cheap method for discriminating plant species, there are some challenges involved when discriminating wetland plant species. It is not easy to detect and discriminate wetland vegetation types using optical remote sensing because of very high spatial and spectral variability, due to very short ecotones between wetland vegetation units (Adam and Mutanga, 2009; Zomer et al., 2009). Thus the selection of the appropriate spatial and spectral resolution and the best process to use to extract the spectral information is of paramount importance (Elhadi et al., 2009). According to the review paper by Adam et al. (2010), hyperspectral remote sensing, especially field spectrometry, is more appropriate and accurate in discrimination of wetland plant species compared to aerial photography and multispectral remote sensing such as Landsat TM and SPOT. This is because hyperspectral sensors have hundreds of narrow continuous spectral bands ranging between 400 to $2500 \mathrm{~nm}$, which make them capable to provide more details on vegetation types (Zomer et al., 2009). In this regard, a research by Smith and Blackshaw (2003) confirmed that plant species discrimination using hyperspectral data yielded more accurate results than that of multispectral data. The research also indicated that the visible $(400-700 \mathrm{~nm})$ and the red edge $(700-730 \mathrm{~nm})$ bands were the regions significantly useful for plant species discrimination. Schmidt and Skidmore (2003) also concluded that increased spectral resolution improved accuracy in discrimination of vegetation species of similar structure in a wetland. The purpose of their research was to discriminate 27 wetland plant species, including Phragmites australis (Cav.) Trin. ex Steud. using field spectrometry. Their results showed that more than $75 \%$ of the possible pairs of plant species showed significant differences based on their spectral reflectance measurements. Furthermore, research by Vaiphasa et al. (2005) concluded that field spectral measurements of crown leaves of various mangrove species were efficient in discriminating mangrove species. In their research a field spectrometer, with 2151 bands ranging from 350 to $2500 \mathrm{~nm}$, was used to measure leaf spectral reflectance of 16 mangrove species. Statistical analysis of the spectral measurements indicated that the 16 species were statistically different at most spectral locations. Adam et al. (2012) also used ASD spectrometry measurements to discriminate among four wetland vegetation species, Cyperus papyrus L., P. australis, Echinochloa pyramidalis and 
Thelypteris interrupta in Greater St Lucia Wetlands Park in South Africa. Van Deventer and Cho (2014) also proved that field spectroscopy can be a quick and cheap method to assess the health and condition of vegetation affected by Acid Mine Drainage.

\section{Conclusion}

Arundo donax L. and Phragmites australis (Cav.) Trin. ex Steud., among other macrophytes, are very important in phytoremediation of heavy metal contaminated wetland systems. Their efficiencies in heavy metal uptake have never been compared under same and controlled environment. While the two species could be important phytoremediating plants, determining their efficiency could help their management as weeds, particularly considering the fact that A. donax is an infamous invader of the water system in South Africa. It will also help determine the effective plant of choice for phytoremediation in constructed wetlands. Remote sensing could be an effective method for monitoring of heavy metal induced stress in both plant species to facilitate their management before they die and release the contaminants removed from water and accumulated in plant tissue back to the source. Although the two plant species are morphologically similar, remote sensing can also effectively discriminate between them. Future research should compare the heavy metal uptake capacities of the two plant species under controlled/experimental conditions, and determine the best remote sensing analysis method to discriminate between the two species, and monitoring their heavy metal uptake capacities.

\section{REFERENCES}

[1] Adam, E., Mutanga, O. (2009): Spectral discrimination of papyrus vegetation (Cyperus papyrus L.) in swamp wetlands using field spectrometry. - ISPRS Journal of Photogrammetry and Remote Sensing 64: 612-620. doi:10.1016/j.isprsjprs.2009.04.004.

[2] Adam, E., Mutanga, O., Rugege, D. (2010): Multispectral and hyperspectral remote sensing for identification and mapping of wetland vegetation: a review. - Wetlands Ecology and Management 18: 281-296. doi:10.1007/s11273-009-9169-z.

[3] Adam, E. M., Mutanga, O., Rugege, D., Ismail, R. (2012): Discriminating the papyrus vegetation (Cyperus papyrus L.) and its co-existent species using random forest and hyperspectral data resampled to HYMAP. - International Journal of Remote Sensing 33: 552-569. doi:10.1080/01431161.2010.543182.

[4] Adams, J. B., Bate, G. C. (1999): Growth and photosynthetic performance of Phragmites australis (Cav.) Trin. ex Steud. in estuarine waters: a field and experimental evaluation. Aquatic Botany 64(3-4): 359-367. https://doi.org/10.1016/S0304-3770(99)00063-7.

[5] Akcil, A., Koldas, S. (2006): Acid Mine Drainage (AMD): causes, treatment and case studies. - Journal of Cleaner Production 14(12-13): 1139-1145. Available at: https://doi.org/10.1016/j.jclepro.2004.09.006.

[6] Allende, M. L., Bektas, M., Lee, B. G., Bonifacino, E., Kang, J., Tuymetova, G., Chen, W., Saba, J. D., Proia, R. L. (2011): Sphingosine-1-phosphate Lyase Deficiency Produces a Pro-inflammatory Response While Impairing Neutrophil Trafficking. - Journal of Biological Chemistry 286: 7348-7358. doi:10.1074/jbc.M110.171819.

[7] Aminsharei, F., Borghei, S. M., Arjomandi, R., Nouri, J., Pendashteh, A. (2017): Seasonal pollutant removal by lactuca sativa, medicago sativa and Phragmites australis (Cav.) Trin. ex Steud. in constructed wetlands. - Applied ecology and environmental research 15(4): 67-76. 
[8] Aryal, R., Nirola, R., Beecham, S., Kamruzzaman, M. (2016): Impact of elemental uptake in the root chemistry of wetland plants. - International Journal of Phytoremediation 18: 936-942. doi:10.1080/15226514.2015.1131239.

[9] Bell, F. G., Bullock, S. E. T., Hälbich, T. F. J., Lindsay, P. (2001): Environmental impacts associated with an abandoned mine in the Witbank Coalfield, South Africa. International Journal of Coal Geology 45(2): 195-216.

[10] Bello, A. O., Tawabini, B. S., Khalil, A. B., Boland, C. R., Saleh, T. A. (2018): Phytoremediation of cadmium-, lead- and nickel-contaminated water by Phragmites australis (Cav.) Trin. ex Steud. in hydroponic systems. - Ecological Engineering 120: 126-133. https://doi.org/10.1016/j.ecoleng.2018.05.035.

[11] Bonanno, G. (2012): Arundo donax L. as a potential biomonitor of trace element contamination in water and sediment. - Ecotoxicology and Environmental Safety 80: 2027. https://doi.org/10.1016/j.ecoenv.2012.02.005.

[12] Bonanno, G. (2013): Comparative performance of trace element bioaccumulation and biomonitoring in the plant species Typha domingensis, Phragmites australis (Cav.) Trin. ex Steud. and Arundo donax L. - Ecotoxicology and Environmental Safety 97: 124-130. https://doi.org/10.1016/j.ecoenv.2013.07.017.

[13] Bragato, C., Brix, H., Malagoli, M. (2006): Accumulation of nutrients and heavy metals in Phragmites australis (Cav.) Trin. ex Steud. (Cav.) Trin. ex Steudel and Bolboschoenus maritimus (L.) Palla in a constructed wetland of the Venice lagoon watershed. Environmental Pollution 144(3): 967-975. https://doi.org/10.1016/j.envpol.2006.01.046.

[14] Bruneau, S. (2017): Wetland Management: A review of policies and practices. Camrose, Alberta: Battle River Watershed Alliance.

[15] Canavan, K., Paterson, I. D., Hill, M. P. (2017): Exploring the Origin and Genetic Diversity of the Giant Reed, Arundo donax. in South Africa. - Invasive Plant Science and Management 10(1): 53-60.

[16] Carson, B. D., Lishawa, S. C., Tuchman, N. C., Monks, A. M., Lawrence, B. A., Albert, D. A. (2018): Harvesting invasive plants to reduce nutrient loads and produce bioenergy: an assessment of Great Lakes coastal wetlands. - Ecosphere 9(6): p.e02320.

[17] Clevers, J. G. P. W., Kooistra, L., Salas, E. A. L. (2004): Study of heavy metal contamination in river floodplains using the red-edge position in spectroscopic data. International Journal of Remote Sensing 25: 3883-3895. doi:10.1080/01431160310001654473.

[18] Coetzee, H., Winde, F., Wade, P. W. (2006): An Assessment of Sources, Pathways, Mechanisms and Risks of Current and Potential Future Pollution of Water and Sediments in Gold-mining Areas of the Wonderfonteinspruit Catchment. - Report to the Water Research Commission. Water Research Comission.

[19] Curran, P. J. (1989): Remote sensing of foliar chemistry. - Remote sensing of Environment 30(3): 271-278.

[20] Davranche, A., Lefebvre, G., Poulin, B. (2010): Wetland monitoring using classification trees and SPOT-5 seasonal time series. - Remote sensing of environment 114(3): 552562.

[21] De Villiers, C., Driver, A., Clark, B., Euston-Brown, D., Day, L., Job, N., Helme, N., Van Ginkel, C. E., Glen, R. P., Gordon-Gray, K. D., Cilliers, C. J. (2011): Easy identification of some South African Wetland Plants. - WRC Report No TT 479(10).

[22] Deng, H., Ye, Z., Wong, M. (2004): Accumulation of lead, zinc, copper and cadmium by 12 wetland plant species thriving in metal-contaminated sites in China. - Environmental Pollution 132: 29-40. doi:10.1016/j.envpol.2004.03.030.

[23] Department of Environmental Affairs (2016): National Environmental Management. Biodiversity Act (10/2004), Alien and Invasive Species Lists, South Africa.

[24] Dubula, B., Tesfamichael, S. G., Rampedi, I. T. (2016): Assessing the potential of remote sensing to discriminate invasive Asparagus laricinus from adjacent land cover types. Cogent Geoscience 2: 1-17. doi:10.1080/23312041.2016.1154650. 
[25] Elhadi, M. A., Mutanga, O., Rugege, D., Ismail, R. (2009): July. Field spectrometry of papyrus vegetation (Cyperus papyrus L.) in swamp wetlands of St Lucia, South Africa. In 2009 IEEE International Geoscience and Remote Sensing Symposium 4: IV-260. IEEE.

[26] Elhawat, N., Alshaal, T., Domokos-Szabolcsy, É., El-Ramady, H., Márton, L., Czakó, M., Kátai, J., Balogh, P., Sztrik, A., Molnár, M., Popp, J., Fári, M. G. (2014): Phytoaccumulation potentials of two biotechnologically propagated ecotypes of Arundo donax in copper-contaminated synthetic wastewater. - Environmental Science and Pollution Research 21: 7773-7780. https://doi.org/10.1007/s11356-014-2736-8.

[27] Emmanuel, D., Elsie, U., Patience, A. (2014): Phytoremediation of xylene polluted environment, using a macrophyte Commelina benghalensis L. - Asian Journal of Plant Science and Research 4: 1-4.

[28] Frick, C. M., Germida, J. J., Farrell, R. E. (1999): December. Assessment of phytoremediation as an in-situ technique for cleaning oil-contaminated sites. - In technical seminar on chemical spills. Environment Canada 1998: 105a-124a.

[29] Gates, D. M., Keegan, H. J., Schleter, J. C., Weidner, V. R. (1965): Spectral properties of plants. - Applied optics 4(1): 11-20.

[30] Gupta, S. K., Nikhil, K. (2016): Ground Water Contamination in Coal Mining Areas: A Critical Review. - International Journal of Engineering and Applied Sciences (IJEAS) ISSN: 3(2): 2394-3661.

[31] Henderson, L. (2001): Alien Weeds and Invasive Plants - A complete guide to declared weeds and invaders in South Africa. - Plant Protection Research Institute Handbook no. 12, - Agricultural Research Council, Pretoria.

[32] Henderson, L., Cilliers, C. J. (2004): Invasive Aquatic Plants. A guide to the identification of the most important and potentially dangerous invasive aquatic plants in South Africa. - PPRI handbook no. 16.

[33] Hirano, A., Madden, M., Welch, R. (2003): Hyperspectral image data for mapping wetland vegetation. - Wetlands 23(2): 436-448.

[34] Horler, D. N. H., Dockray, M., Barber, J. (1983): The red edge of plant leaf reflectance. International Journal of Remote Sensing 4: 273-288.

[35] Ilfergane, A. (2016): Investigations on the effects of Typha capensis on male reproductive functions. - Doctoral dissertation, University of the Western Cape.

[36] Kaewtubtim, P., Meeinkuirt, W., Seepom, S., Pichtel, J. (2016): Heavy metal phytoremediation potential of plant species in a mangrove ecosystem in Pattani Bay, Thailand. - Appl Ecol Environ Res 14(1): 367-382.

[37] Kalra, Y. P. (1998): Handbook of Reference Methods for Plant Analysis. - CRC Press. Taylor and Francis Group, Boca Raton, FL.

[38] Kaplan, D. I., Buettner, S. W., Li, D., Huang, S., van Groos, P. G. K., Jaffé, P. R., Seaman, J. C. (2017): In situ porewater uranium concentrations in a contaminated wetland: Effect of seasons and sediment depth. - Applied Geochemistry 85: 128-136.

[39] Knipling, E. B. (1970): Physical and physiological basis for the reflectance of visible and near-infrared radiation from vegetation. - Remote Sensing of Environment 1: 155-159. https://doi.org/10.1016/S0034-4257(70)80021-9.

[40] Kumari, M., Tripathi, B. D. (2015): Efficiency of Phragmites australis and Typha latifolia for heavy metal removal from wastewater. - Ecotoxicology and Environmental Safety 112: 80-86. doi:10.1016/j.ecoenv.2014.10.034.

[41] Laghlimi, M., Baghdad, B., El Hadi, H., Bouabdli, A. (2015): Phytoremediation mechanisms of heavy metal contaminated soils: a review. - Open journal of Ecology 5(08): 375.

[42] Lambert, A. M., Dudley, T. L., Saltonstall, K. (2010): Ecology and Impacts of the LargeStatured Invasive Grasses Arundo donax and Phragmites australis in North America. Invasive Plant Science and Management 3: 489-494. doi:10.1614/IPSM-D-10-00031.1. 
[43] Leguizamo, M. A. O., Gómez, W. D. F., Sarmiento, M. C. G. (2017): Native herbaceous plant species with potential use in phytoremediation of heavy metals, spotlight on wetlands - a review. - Chemosphere 168: 1230-1247.

[44] Lepp, N. W. (1975): The potential of tree-ring analysis for monitoring heavy metal pollution patterns. - Environmental Pollution 9(1): 49-61.

[45] Li, Q. T., Yang, F. J., Zhang, B., Zhang, X., Zhou, G. Z. (2008): Biogeochemistry responses and spectral characteristics of Rhus chinensis Mill under heavy metal contamination stress. - Journal of Remote Sensing -Beijing 12(2): 290.

[46] Liu, J., Dong, Y., Xu, H., Wang, D., Xu, J. (2007): Accumulation of Cd, Pb and Zn by 19 wetland plant species in constructed wetland. - Journal of Hazardous Materials 147: 947953. doi:10.1016/j.jhazmat.2007.01.125.

[47] Liu, Y., Chen, H., Wu, G., Wu, X. (2010): Feasibility of estimating heavy metal concentrations in Phragmites australis. using laboratory-based hyperspectral data. A case study along Le'an River, China. - International Journal of Applied Earth Observation and Geoinformation 12: S166-S170. https://doi.org/10.1016/j.jag.2010.01.003.

[48] Luo, S., Wang, C., Xi, X., Pan, F., Qian, M., Peng, D., Nie, S., Qin, H., Lin, Y. (2017): Retrieving aboveground biomass of wetland Phragmites australis (common reed) using a combination of airborne discrete-return LiDAR and hyperspectral data. - International Journal of Applied Earth Observation and Geoinformation 58: 107-117.

[49] Lusweti, A., Wabuyele, E., Ssegawa, P., Mauremootoo, J. R. (2011): Invasive plants of East Africa (Kenya, Uganda and Tanzania). - Lucid v. 3.5 key and fact sheets, National Museums of Kenya, Makerere University, BioNET-EAFRINET, CABI and the University of Queensland, keys.lucidcentral.org/keys/v3/EAFRINET. Accessed 3 August 2017.

[50] Masoko, P., Mokgotho, M. P., Mbazima, V. G., Mampuru, L. J. (2008): Biological activities of Typha capensis (Typhaceae) from Limpopo Province (South Africa). African Journal of Biotechnology 7(20).

[51] Matagi, S., Swai, D., Mugabe, R. (1998): A review of Heavy Metal Removal Mechanisms in wetlands. - African Journal of Tropical Hydrobiology and Fisheries 8(1): 13-25. https://doi.org/10.4314/ajthf.v8i1.1386.

[52] McCarthy, T. S., Humphries, M. S. (2013): Contamination of the water supply to the town of Carolina, Mpumalanga, January 2012. - South African Journal of Science 109: 01-10.

[53] Milton, S. J. (2004): Grasses as invasive alien plants in South Africa: working for water. - South African Journal of Science 100: 69-75.

[54] Mojiri, A., Aziz, H. A., Tajuddin, R. B. M., Gavanji, S., Gholami, A. (2015): Heavy Metals Phytoremediation from Urban Waste Leachate by the Common Reed (Phragmites australis). - In: Phytoremediation. Springer, Cham, pp. 75-81. Available at: https://doi.org/10.1007/978-3-319-10969-5_7.

[55] Newete, S. W., Byrne, M. J. (2016): The capacity of aquatic macrophytes for phytoremediation and their disposal with specific reference to water hyacinth. Environmental Science and Pollution Research 23: 10630-10643. doi:10.1007/s11356016-6329-6.

[56] Newete, S. W., Erasmus, B. F. N., Weiersbye, I. M., Byrne, M. J. (2016): Sequestration of precious and pollutant metals in biomass of cultured water hyacinth (Eichhornia crassipes). - Environmental Science for Pollution Research 23: 20805-20818. https://doi.org/10.1007/s11356-016-7292-y.

[57] Ochieng, G. M., Seanego, E. S., Nkwonta, O. I. (2010): Impacts of mining on water resources in South Africa: A review. - Scientific Research and Essays 5(22): 3351-3357.

[58] Papazoglou, E. G., Karantounias, G. A., Vemmos, S. N., Bouranis, D. L. (2005): Photosynthesis and growth responses of giant reed (Arundo donax L.) to the heavy metals Cd and Ni. - Environment International 31: 243-249. doi:10.1016/j.envint.2004.09.022. 
[59] Pilon-Smits, E. (2005): Phytoremediation. - Annu. Rev. Plant Biol. 56: 15-39. - Pollution Bulletin 42(10): 811-816.

[60] $\mathrm{Pu}$, R. (2009): Broadleaf species recognition with in situ hyperspectral data. International Journal of Remote Sensing 30(11): 2759-2779.

[61] Ramsar Convention Secretariat (2016): An Introduction to the Convention on Wetlands (previously The Ramsar Convention Manual). - Ramsar Convention Secretariat, Gland, Switzerland.

[62] Raskin, I., Smith, R. D., Salt, D. E. (1997): Phytoremediation of metals: using plants to remove pollutants from the environment. - Current opinion in biotechnology 8: 221-226.

[63] Rizwan, M., Ali, S., Qayyum, M. F., Ok, Y. S., Zia-ur-Rehman, M., Abbas, Z., Hannan, F. (2017): Use of Maize (Zea mays L.) for phytomanagement of Cd-contaminated soils: a critical review. - Environmental geochemistry and health 39(2): 259-277.

[64] Rouget, M., Richardson, D. M., Nel, J. L., Le Maitre, D. C., Egoh, B., Mgidi, T. (2004): Mapping the potential ranges of major plant invaders in South Africa, Lesotho and Swaziland using climatic suitability. - Diversity and Distributions 10(5-6): 475-484.

[65] Rouse Jr, J. W. (1974): Monitoring the vernal advancement and retrogradation (green wave effect) of natural vegetation. - Type I Progress Report Number 6, Texas University, Remote sensing center.

[66] Sasmaz, A., Obek, E., Hasar, H. (2008): The accumulation of heavy metals in Typha latifolia L. grown in a stream carrying secondary effluent. - Ecological Engineering 33: 278-284. doi:10.1016/j.ecoleng.2008.05.006.

[67] Schmidt, K. S., Skidmore, A. K. (2003): Spectral discrimination of vegetation types in a coastal wetland. - Remote Sensing of Environment 85: 92-108. doi:10.1016/S00344257(02)00196-7.

[68] Shakya, K., Chettri, M. K., Sawidis, T. (2008): Impact of Heavy Metals (Copper, Zinc, and Lead) on the Chlorophyll Content of Some Mosses. - Archives of Environmental Contamination and Toxicology 54: 412-421. https://doi.org/10.1007/s00244-007-9060-y.

[69] Sheoran, A. S., Sheoran, V. (2006): Heavy metal removal mechanism of acid mine drainage in wetlands: A critical review. - Minerals Engineering 19: 105-116. doi:10.1016/j.mineng.2005.08.006.

[70] Shuai, W., Chen, N., Li, B., Zhou, D., Gao, J. (2016): Life cycle assessment of common reed ( Phragmites australis (Cav) Trin. ex Steud ) cellulosic bioethanol in Jiangsu Province, China. - Biomass and Bioenergy 92: 40-47. Available at: https://doi.org/10.1016/j.biombioe.2016.06.002.

[71] Shuping, L. S., Snyman, R. G., Odendaal, J. P., Ndakidemi, P. A. (2011): Accumulation and distribution of metals in Bolboschoenus maritimus (Cyperaceae), from a South African river. - Water, Air, and Soil Pollution 216(1-4): 319-328.

[72] Smith, A. M., Blackshaw, R. E. (2003): Weed-Crop Discrimination Using Remote Sensing: A Detached Leaf Experiment. - Weed Technology 17(4): 811-820.

[73] Sridhar, B. B. M., Han, F. X., Diehl, S. V., Monts, D. L., Su, Y. (2007): Spectral reflectance and leaf internal structure changes of barley plants due to phytoextraction of zinc and cadmium. - International Journal of Remote Sensing 28: 1041-1054. doi:10.1080/01431160500075832.

[74] US Department of State Geographer (2018): AfriGIS (Pty) Ltd. - Google earth. Image accessed on 9 January 2019.

[75] Usharani, B., Vasudevan, N. (2016): Impact of heavy metal toxicity and constructed wetland system as a tool in remediation. - Archives of environmental and occupational health 71(2): 102-110.

[76] Vaiphasa, C., Ongsomwang, S., Vaiphasa, T., Skidmore, A. K. (2005): Tropical mangrove species discrimination using hyperspectral data: A laboratory study. Estuarine, Coastal and Shelf Science 65: 371-379. doi:10.1016/j.ecss.2005.06.014.

[77] Van der Merwe, C. G., Schoonbee, H. J., Pretorius, J. (1990): Observations on concentrations of the heavy metals zinc, manganese, nickel and iron in the water, in the 
sediments and in two aquatic macrophytes, Typha capensis (Rohrb.) N. E. Br. and Arundo donax L., of a stream affected by goldmine and industrial effluents. - Water S. A. 16(2): 119-124.

[78] Van Deventer, H., Cho, M. A. (2014): Assessing leaf spectral properties of Phragmites australis impacted by acid mine drainage. - South African Journal of science 110: 1-12.

[79] Vassilev, A., Schwitzguébel, J. P., Thewys, T., Van Der Lelie, D., Vangronsveld, J. (2004): The use of plants for remediation of metal-contaminated soils. - The Scientific World Journal 4: 9-34.

[80] Vymazal, J., Březinová, T. (2015): The use of constructed wetlands for removal of pesticides from agricultural runoff and drainage: a review. - Environment international 75: 11-20.

[81] Vymazal, J., Březinová, T. (2016): Accumulation of heavy metals in aboveground biomass of Phragmites australis in horizontal flow constructed wetlands for wastewater treatment: A review. - Chemical Engineering Journal 290: 232-242. doi:10.1016/j.cej.2015.12.108.

[82] Wong, M. H. (2003): Ecological restoration of mine degraded soils, with emphasis on metal contaminated soils. - Chemosphere 50(6): 775-780.

[83] Yang, X., Feng, Y., He, Z., Stoffella, P. J. (2005): Molecular mechanisms of heavy metal hyperaccumulation and phytoremediation. - Journal of Trace Elements in Medicine and Biology 18(4): 339-353. https://doi.org/10.1016/j.jtemb.2005.02.007.

[84] Yang, B., Lan, C. Y., Yang, C. S., Liao, W. B., Chang, H., Shu, W. S. (2006): Long-term efficiency and stability of wetlands for treating wastewater of a lead/zinc mine and the concurrent ecosystem development. - Environmental Pollution 143: 499-512. doi:10.1016/j.envpol.2005.11.045.

[85] Zedler, J. B., Kercher, S. (2004): Causes and consequences of invasive plants in wetlands: opportunities, opportunists, and outcomes. - Critical Reviews in Plant sciences 23(5): 431-452.

[86] Zingelwa, N. S., Wooldridge, J. (2016): Uptake and accumulation of mineral elements from winery and distillery effluents by Typha latifolia and Phragmites australis. - South African Journal of Enology and Viticulture 30(1): 43-48.

[87] Zomer, R. J., Trabucco, A., Ustin, S. L. (2009): Building spectral libraries for wetlands land cover classification and hyperspectral remote sensing. - Journal of Environmental Management 90: 2170-2177. doi:10.1016/j.jenvman.2007.06.028.

[88] Zwiggelaar, R. (1998): A review of spectral properties of plants and their potential use for crop/weed discrimination in row-crops. - Crop Protection 17(3): 189-206. 